\title{
Maximizing Income Through Capital, Raw Materials, Labor and Production
}

\author{
Abdul Gani ${ }^{1}$, Zulia Rifda Daulay ${ }^{2}$ \\ ${ }^{1}$ Akuntansi Perpajakan, Politeknik Unggul LP3M \\ Sumatera Utara Indonesia. \\ ${ }^{2}$ Manajemen Pemasara, Politeknik Unggul LP3M \\ Sumatera Utara Indonesia \\ ${ }^{*}$ Corresponding author: \\ Email: zulia rifda@yahoo.co.id
}

\begin{abstract}
.
The purpose of this study was to analyze the effect of capital, raw materials, labor and production on business income for the Batu Bara songket cloth during the Covid-19 pandemic. The data analysis model used is multiple linear regression analysis. The population and sample of 65 craftsmen of Batu Bara songket cloth were used as research samples. Data collection techniques using a questionnaire (questionnaire) with a Likert scale. For data processing using the SPSS Version 22 application. The results showed that all variables of capital, raw materials, labor and production had a positive and significant impact on the business income of Batu Bara songket cloth. The variable that has the greatest influence in increasing business income for the Batu Bara songket cloth is labor.
\end{abstract}

Keywords: Capital, Raw Materials, Energy, Production, Income

\section{INTRODUCTION}

Small and medium enterprises are expected to have the ability to survive with high levels of competition [1]. One of the efforts that must be made is to continue to increase existing income [2]. By having maximum income, of course, it will provide MSMEs to continue to innovate and improve in increasing their sales volume [3]. Income is very influential for the continuity of a business, the greater the income obtained, the greater the ability of a business to finance all expenses and activities to be carried out. A person's condition can be measured by using the concept of income which shows the total amount of money received by a person from the household during a certain period of time [4].

The main objective of running a trading business is to make a profit [5]. Income according to the acquisition is the gross income generated from the sale of merchandise or the total sales turnover obtained before being deducted by expenses and other expenses, while net income is the revenue from sales minus the purchase of materials, transportation costs, levies or total revenue from revenue minus total costs ( cost) [6].. However, there are also factors that affect income such as job opportunities available, skills and expertise, motivation, tenacity to work and how much capital is used [7]. 
Capital is all forms of wealth that are used in the production process or produce output. Capital is wealth that can generate profits in the future. Capital is an asset that is used to assist the distribution of subsequent assets. Talking about capital, many people connote an amount of money or an injection of funds that can help build a business or develop it [8].. Some of the businesses that are run come from their own capital before the business develops, but if their own capital is not sufficient, they can borrow capital from other parties, while the capital itself is capital obtained from the business owner itself consisting of savings, donations, grants, relatives, and others. so on [9].. The results of previous studies show that capital has a positive and significant effect on income [10].

In an industry, both home industry and large-scale industries certainly have a raw material and its types that are processed and processed as a product [6]. Raw materials are also an important factor affecting income. Raw materials are a production factor needed in every production process, the greater the amount of raw materials owned, the greater the possibility of the number of products produced, so that the possibility of income received is greater from the sales of its production Raw materials are the amount of materials needed to carry out the production process within a certain period of time. inventory of raw materials within the company is very important to be controlled properly, so that the company can generate optimal income [11]. Based on previous research that supports this study that the direct effect of raw materials on income [5].

Labor is a very important factor in production, because labor is the driving factor for other input factors, without labor, other production factors will be meaningless [12].. The increase in labor productivity will encourage an increase in production so that income will also increase [13]. If many products are sold, the entrepreneur will increase the amount of production. The increase in the amount of production will result in an increase in the labor required, so that the income will also increase [9].. This means that labor partially has a positive and significant effect on income [14].Production can also be referred to as the process of creating goods and services. Goods and services are often bought and sold for public consumption [5]. Goods and services are the output of production operations. To produce production factors, tools or means are needed to carry out production peruses [11]. The results of previous studies state that there is a positive and significant influence between production on income [15]. So that production can be concluded that every human interest in accordance with the rules of the Shari'a must be the target of a production activity, where production is the process of seeking to allocate resources into output (expenditure) in order to increase the benefit of humans [12]..

Coal Regency is located in North Sumatra Province, which is an expansion area from Asahan Regency with an area located on the east coast of North Sumatra towards the South. The people of Coal are dominated by the Malay tribe because they live in coastal areas and most of the people are fishermen because they live in coastal areas 
and there are also residents who work as farmers. In addition, the district of Batu bara is famous for Tenun Songket which is a small industry that is growing rapidly because songket is one of the culture and identity of the Malay community.

One of the coal songket entrepreneurs is Mrs. Ratna as the owner of UD Yusra "Songket House". Mrs. Ratna (62 years) comes from the village of Padang Genting, District of Talawi. He has been in this business for a long time since 1970 with a workforce of 65 people. The songket fabric uses traditional weaving tools (okik) and is done manually. The raw materials for making coal songket such as polyester yarn, silk thread, gold thread and silver thread are obtained from Jakarta, Pematang Siantar city, Kisaran and Medan city but the development of digital technology, raw materials can be purchased through online media because the raw materials are in a Industrial activities play a very important role in being able to produce quality finished goods such as songket cloth, wedding clothes, kebaya and scarves with various fabric motifs and colors which are characteristic of Batu Bara Malay which has a fairly high artistic and cultural value.

One of the perpetrators on behalf of Mrs. Ratna opened this business with her own capital after the development of songket cloth production from year to year inspired the government to help coal songket craftsmen in the form of loan money through bank credit with very minimal interest in order to help craftsmen in the development of songket weaving production. Coal is of higher quality and is in demand by the people of Medan, Pekan Baru, Jakarta, Kalimantan and even to neighboring countries such as Malaysia, Thailand, Singapore and Brunei Darussalam.

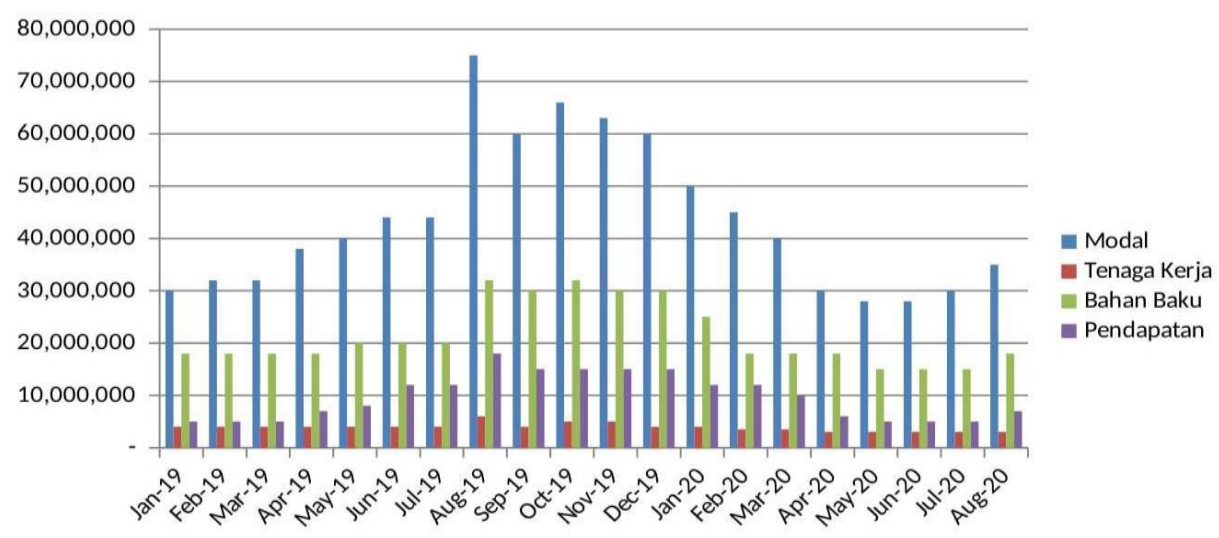

Fig 1: Data from UD Yusra Songket's income report

From the picture above, it can be seen that from January 2019 to July 2019 there were fluctuations in capital, labor, raw materials and income but in August 2019 there was a very drastic increase in orders because the officials of the Coal Regency were "obliged" to wear traditional Malay clothes. in the commemoration ceremony on August 17, 2019. January 2020 until now seen from the picture above shows a decline in all factors related to the income and production of Batu Bara songket cloth due to an 
issue that spreads in the community that it is not permissible to hold parties or celebrations of religious and national holidays because The Covid 19 outbreak is very dangerous. As a result, orders for Batu Bara songket have dropped dramatically. Songket business becomes sluggish, the craftsmen only work on the songket cloth according to order so that it greatly affects the income for the Batu Bara songket craftsmen.

\section{METHODS}

The location of this research was conducted in Talawi District, Kab. Coal with a discussion of the income of coal songket craftsmen during the Covid-19 pandemic which affected capital, raw materials, labor and production. The type used is quantitative data, which is data in the form of numbers and can be calculated in units. In this study, the quantitative data used are capital, raw materials, production labor and income. data qualitative data in the form of explanations or descriptions [16]. In this study, in the form of qualitative data used are theories and explanations of capital, raw materials, production labor and income.

Sources of data in this study consisted of primary data and secondary data. Primary data is collected by the researcher directly from the first source or the place where the research is conducted through a questionnaire (questionnaire) and interviews. Secondary data is data that is collected and published by other parties. Secondary data used in this study were obtained from administration and bookkeeping and financial reports of UD Yusra Songket in 2019 and 2020. The measurement scale uses a Likert scale with a value of 1-5. Where 1 (Strongly Disagree), 2 (Disagree), 3 (Doubt), 4 (Agree), 5 (Strongly Agree).

Respondents in this study were craftsmen of the coal songket cloth in Talawi District, Batu bara Regency. This study took a total population of 65 craftsmen of Batu bara songket cloth in Talawi District as a sample in this study because if the subject is less than 100 , the entire population can be taken so that the study is a population study [17].The data analysis technique uses the help of the SPSS 22 application program to determine the direct effect between the variables of capital, raw materials, labor and production on the variable income of coal songket craftsmen during the Covid-19 pandemic using the equation:

$$
\mathrm{Y}=\alpha+\beta 1 \mathrm{X} 1+\beta 2 \mathrm{X} 2+\beta 3 \mathrm{X} 3+\beta 4 \mathrm{X} 4+\mathrm{e}
$$

Information :

Y: Income (Rupiah)

X1: Capital (Rupiah)

X2: Raw Materials (Rupiah)

X3: Labor (Person)

$\mathrm{X} 4$ : Production (Unit of Goods) 
$\alpha$ : Constant

$\beta 1 . \beta 2 \beta 3 \beta 4$ : Regression Coefficient for each variable

e: Error

\section{RESULT AND DISCUSSION \\ The Influence of Capital on Income}

The results of the analysis show that capital has a positive and significant effect on the income of the coal songket craftsmen. This means that the higher the capital, the higher the income of the coal songket craftsmen. Vice versa, the lower the capital, the lower the income earned by the coal songket craftsmen. Capital is very important for every production process, without capital, production will not run smoothly [18]. Where the higher the capital, the industry's income will increase. Therefore, the existence of capital will affect the income to be received.

Capital with a large quantity can provide opportunities for a large amount of profit compared to the situation with a relatively small amount of capital [4]. If capital increases, production will increase so that it can increase income [5]. This study supports some of the results of previous studies and is consistent with the results of research [7][19][20] which found that capital has a positive and significant effect on income.

\section{Effect of Raw Materials on Income}

The results of the analysis show that raw materials have a positive and significant effect on income. This means that the more raw materials provided, the higher the income earned by the coal songket craftsmen. Vice versa, the less raw materials used, the less income will be earned by the coal songket craftsmen. These results indicate that raw material is also an important factor affecting income [21]. The greater the amount of raw materials owned, the greater the possibility of the number of products produced 15]. So that the possibility of income received is greater from the sales of its production.

Raw material is a production factor needed in the production process [22].. Inventory of raw materials in the company is very important to be controlled properly, so that it can generate optimal income [5]. This study supports some of the results of previous studies and is consistent with the results of research [10][23][24] which found that raw materials partially have a positive effect on income.

\section{Effect of Labor on Income}

The results of the analysis show that labor has a positive and significant effect on income. This means that the more labor that is used, the more amount of production will be produced, thereby increasing the income that can be obtained [14].. Vice versa, the less labor is used, the lower the amount of production produced [4].. This shows that labor is a very important factor in production [9]. Because labor is the driving factor for other input factors, without labor, other 
production factors will be meaningless [13].. Increasing labor productivity will encourage increased production and will have an impact on increasing income [8]. The results of this study are in accordance with the results of research [9][10][14] which obtained results that labor has a positive and significant effect on income.

\section{The Effect of Production on Income}

The results of the analysis show that production has a positive and significant effect on income. This means that the greater the amount of production produced, the more income that can be obtained. Vice versa, the less labor is used, the lower the amount of production produced, which affects the income earned by the coal songket craftsmen. This shows that production is a very important factor in increasing the income of UMKM craftsmen [25].. With the increase in production which produces quality products will encourage increased income for the craftsmen [26]. The results of this study are in accordance with the results of research [11][12] which obtained results that production has a positive and significant effect on income of coal songket craftsmen.

\section{CONCLUSION}

Based on the results of the research and discussion above, the conclusions in this study are as follows:

1. That capital has a significant effect on the income of the coal songket craftsmen.

2. That the raw material has a positive and significant effect on the income of the coal songket craftsmen.

3. That labor has a positive and significant effect on the income of coal songket craftsmen.

4. That the production has a positive and significant effect on the income of the coal songket craftsmen.

\section{ACKNOWLEDGMENTS}

The authors thank the songket cloth business actors in Batu Bara who have provided the necessary permits and data sources. In addition, the authors would like to thank, especially the Director of Research and Community Service (DRPM) who has provided research funding support through a research program grant for beginner lecturers.

\section{REFERENCES}

[1] A. A. E. D. Sunarsi, "Persepsi Mahasiswa Terhadap Kemampuan Dalam Mendirikan UMKM Dan Efektivitas Promosi Melalui Online Di Kota Tangerang Selatan,” J. Ilm. MEA (Manajemen, Ekon. dan Akuntansi), vol. 4, no. 3, pp. 702-714, 2020.

[2] Y. F. L. A. H. Setiawan, "Analisis Faktor-Faktor Yang Mempengaruhi Pendapatan UMKM Sentra Batik Di Kota Pekalongan," Diponegoro J. Econ., vol. 9, no. 4, pp. 1$10,2020$. 
[3] I. M. H. K. N. P. Juniari, “Aktor Faktor Yang Mempengaruhi Pendapatan Umkm Pandan Wangi Di Desa Tumbakbayuh Kecamatan Mengwi Kabupaten Badung," J. Appl. Manag. Account. Sci. ( J A M A S ), vol. 02, no. 1, pp. 67-73, 2020.

[4] P. M. P. D. S. . E. K. D. Tolosang, "Analisis Pengaruh Modal, Lama Usaha, Dan Jumlah Tenaga Kerja Terhadap Pendapatan Usaha Mikro Kecil Dan Menengah Di Kecamatan Langowan Timur,” J. Berk. Ilm. Efisiensi, vol. 19, no. 04, pp. 36-47, 2019.

[5] N. G. V. . A. J. M. M. T. B. Maramis, "Analisis Pengaruh Modal Dan Biaya Produksi Terhadap Pendapatan UMKM Di Kota Kotamobagu," J. Berk. Ilm. Efisiensi, vol. 19, no. 01, pp. 56-67, 2019.

[6] D. I. S. M. O. Wiraswati, "Pengaruh Biaya Produksi Dan Laba Yang Diinginkan Terhadap Harga Jual Pada UMKM Dua Putri Beton,” Ecobuss, vol. 8, no. 2, pp. 81-91, 2020.

[7] R. L. H. D. N. K. D. P. Alamsyah, "Pengaruh Modal, Tingkat Pendidikan Dan Teknologi Terhadap Pendapatan UMKM Di Kabupaten Purbalingga," J. Ekon. Dan Bisnis, vol. 17, no. 2, pp. 305-313, 2020.

[8] M. F. A. Widiyanto, "Pengaruh Karakteristik Wirausaha, Modal Usaha Dan Tenaga Kerja Terhadap Keberhasilan UMKM Batik," Econ. Educ. Anal. J., vol. 7, no. 2, pp. 761-776, 2018.

[9] A. P. S. M. Z, "Pengaruh Modal, Jam Kerja, dan Jumlah Tenaga Kerja Terhadap Pendapatan Pengusaha UMKM Berbasis Kuliner Di Kecamatan Banjarmasin Timur," JIEP J. Ilmu Ekon. dan Pembang., vol. 2, no. 3, pp. 576-589, 2019.

[10] K. W. N. I. N. Kartika, "Pengaruh Modal, Tenaga Kerja Dan Bahan Baku Terhadap Pendapatan Pengusaha Industri Sanggah Di Kecamatan Mengwi," E-Jurnal Ekon. dan Bisnis Univ. Udayana, vol. 7, no. 8, pp. 1927-1956, 2018.

[11] I. Mbae, "Pengaruh Produksi Terhadap Pendapatan Pabrik Tahu Sumber Sari Kelurahan Gebang Rejo Poso," J. Ekomen, vol. 16, no. 1, pp. 12-18, 2016.

[12] J. Pertanian and A. Vol, "Pengaruh Biaya Sarana Produksi Dan Tenaga Kerja Terhadap Pendapatan Usahatani Padi Inpari," Ahimzha Ibnu Wiharnata; Sumardii; Saparto, vol. 23, no. 1, pp. 121-133, 2021.

[13] R. M. S. U. Nurbayani, "Pengaruh Modal Usaha, Tenaga Kerja Dan Lama Usaha Terhadap Laba Usaha Mikro Di Kota Palopo Provinsi Sulawesi Selatan," J. Manaj., vol. 4, no. 2, pp. 43-47, 2018.

[14] D. M. A. Mahmud, "Pengaruh Kredit Usaha Rakyat (KUR), Total Aset, Jumlah Tenaga Kerja, Biaya Pemasaran Dan Lokasi Usaha Terhadap Pendapatan Usaha Mikro Kecil Dan Menengah (UMKM) Berbasis Ekonomi Kreatif Di Kota Semarang," Bus. Account. Educ. J., vol. 1, no. 3, pp. 247-257, 2020.

[15] F. H. R. D. S. Ferawati, "Analisis Pengaruh Pemberian Modal Kerja Dan Biaya Produksi Terhadap Peningkatan Pendapatan Usaha Kecil Menengah Di Desa Pongkar Kecamatan Tebing Kabupaten Karimun (Tahun 2014 - 2018)," J. Cafe., vol. 1, no. 1, pp. 63-73, 2020.

[16] R. H. Rusiadi, Nur Subiantoro, Metode Penelitian Manajemen, Akuntansi dan Ekonomi Pembangunan (Konsep, Kasus dan Aplikasi SPSS, Eviews, Amos, Lisres). Medan: USU Press, 2014.

[17] Sugiyono, Metode Penelitian. Bandung: Alfabeta, 2016.

[18] B. Prihatminingtyas, "Pengaruh Modal, Lama Usaha, Jam Kerja Dan Lokasi Usaha Terhadap Pendapatan Pedagang Di Pasar Landungsari," Ref. J. Ilmu Manaj. dan Akutansi, vol. 7, no. 2, pp. 147-154, 2019.

[19] S. Ubaidillah, "Pengaruh Modal Terhadap Pendapatan Pedagang ( Studi kasus: Pasar Angso Duo Kota Jambi )," Eksis J. Ilm. Ekon. dan Bisnis, vol. 11, no. November, pp. 137-141, 2020.

[20] N. N. I. I. I. R. M. M. A. Zainuddin, "Pengaruh Modal Kerja dan Jam Kerja Terhadap 
Pendapatan Pedagang Kaki Lima di Kelurahan Kabonena,” J. Ilmu Ekon. dan Bisnis Islam - JIEBI, vol. 2, no. 1, pp. 1-16, 2020.

[21] P. C. P. P. S. Devi, "Pengaruh Bahan Baku, Management Supplay Chain, Dan Modal Terhadap Pendapatan Pedagang Sate Di Kecamatan Abiansemal Kabupaten Badung Tahun 2020," JIMAT (Jurnal Ilm. Mhs. Akuntansi), vol. 11, no. 3, pp. 597-606, 2020.

[22] Y. V. F. N. R. Zulyanti, "Pengaruh Dimensi Sosial, Sumber Daya Manusia Dan Bahan Baku Terhadap Pengrajin Industri Gerabah," J. Manag. Rev., vol. 3, no. 2, pp. 350356, 2019.

[23] D. Maryanto, "Pengaruh Persediaan Bahan Baku Terhadap Laba Bersih Perusahaan Pada PT. Yokogawa Indonesia,” J. Lentera Akunt., vol. 5, no. 2, pp. 1-22, 2020.

[24] F. W. A. M. R. Ramadhan, “Analisis Pengaruh Layout Penyimpanan Bahan Baku terhadap First In First Out Berdasarkan Hasil Jajak Pendapat Karyawan ( Studi pada PT Indofood CBP Sukses Makmur TBK Divisi Packaging Purwakarta )," J. Logistik Indones., vol. 4, no. 2, pp. 114-126, 2020.

[25] A. G. M. R. N. I. A. F. Hasan, "Pengaruh Jumlah Produksi Dan Kualitas Sdm Terhadap Pendapatan Karyawan Pada Konveksi Hijab Al - Vieta Tunggul Paciran," Media Mahard., vol. 9, no. 1, pp. 1-6, 2020.

[26] D. S. P. K. S. A. F. U. FR, "Analisis Pendapatan Dan Pengaruh Penggunaan Input Produksi Pada Usahatani Kedelai Di Kabupaten Lombok Tengah," JIA (Jurnal IIm. Agribisnis) J. Agribisnis dan Ilmu Sos. Ekon. Pertan., vol. 5, no. 4, pp. 141-149, 2020. 